\title{
Tourism Village Development Strategy to Increasing Tourist Visits
}

\author{
Aries Kurniawan*, Beni Dwi Komara, Heri Cahyo Bagus Setiawan, Nanang \\ Bagus Setiawan
}

\author{
Study Program of Entrepreneurship, Economy and Business Faculty, Universitas Muhammadiyah Gresik, \\ Gresik, Indonesia \\ *Corresponding author email: ariesaja@umg.ac.id
}

\begin{abstract}
The purpose of this study was to determine the strategies used by the management of Hendrosari Tourism Village in increasing the number of tourist visits. Hendrosari Village, located in Menganti District, Gresik Regency, East Java Province, has a Wista village called Eduwisata Lontar Sewu. Education, which has a tourism concept in the industrial era 4.0, is managed by Village-Owned Enterprises and Village Community Economic Business Groups under the coordination of the local Village Government. This tour relies on tourist attractions with instagramable photo spots. Besides, they also provide playgrounds for children and various local village culinary delights. This research is a descriptive study with qualitative data. The technique of collecting data was done by interviewing, observing, and documenting the informants using purposive sampling technique. Tourism product development strategies that can be carried out are in the form: 1) Developing instagramable photo spots by increasing the number of photos and visitors published on Instagram, Facebook, and YouTube. 2) Developing tourism vehicles by providing new tourism vehicles in the form of an All-Terrain Vehicle in existing tourist areas. 3) Arrange traders around tourist attractions to be tidier, cleaner, and more orderly. 4) Increase the enthusiasm of YouTubers to neutralize tourist attractions.
\end{abstract}

Keywords: Tourism, Village, Development

\section{INTRODUCTION}

Currently there is an alternative vacation that is popular with parents to invite their children not only to enjoy nature, but also to have educational value for children. Vacations with the concept of education, which offer education and tourism. The popularity of this type of tourism is indeed increasing and in great demand.

This kind of concept is not new, even abroad the concept of education has long been developed and offered in various forms. Like one of the many educational training camps held in the summer. Not only is the joy offered, the camp also provides a lot of practical education provisions such as leadership to daily skills. In Indonesia, activists in the realm of this business are not as big as those abroad. However, there are several educational concepts that have been successfully developed and have attracted the interest of the community. Lontar Sewu tourism which is located in Hendrosari Village, Menganti District, Gresik Regency is a tourist spot that relies on the natural beauty of palm trees. The tourism manager in this case BUMDesa Hendrosari, the Village Government and the Village Community makes tourist objects with the concept of preserving nature. About a thousand palm trees that grow in the village, which is located in Menganti District Gresik Regency, are used as an Instagramable tourist attraction. [1]. Currently, managers make tourist objects by relying on natural beauty and interesting photo spots. A deck or bridge made of wood is built on agricultural land that is overgrown with palm trees. In addition, they equip them with playgrounds for children. So that with this concept all family members can enjoy the available tourist attractions.

Previous research that has used the concept of experiential marketing on tourist attractions, among others, was carried out by Jatmiko and Andharini (2012) at the Sengkaling Recreation Park in Malang [2], and by Tsaur, Chiu, Wang (2006) at the Taipei Zoo. Experiential marketing at Taipei Zoo focuses on the consumer experience. Since this concept was implemented by the Taipei Zoo, the place, which has only focused on functional features and benefits, has turned into a more impressive impression and experience for visitors by using five basic elements, namely: sense, feel, think, act, and relate. [3]. The development of tourist conditions and current conditions requires tourism managers to innovate and update product development strategies. In addition to using the concept of experiential marketing as a consideration in developing a development strategy, the current conditions of the four components of tourist attraction, namely attraction, accessibilities, amenities, and ancillary (institutional) [4] will also be input to strategy development.

\section{RESEARCH METHOD}

This study uses a descriptive method using qualitative analysis through analysis using a scientific approach in accordance with the actual 
situation. the sample is called the informant, namely the person who is the source of the information. Determining the subjects in this study, researchers used Porposeful Sampling, which is based on the characteristics of the selected subjects because these characteristics are in accordance with the objectives of the research to be carried out [5]. Based on the considerations, the informants in this study were:

1. Head of Village

2. Head of BUMDesa \& 2 member.

3. Six tourist.

The data used in this qualitative research are primary data and secondary data obtained from various sources. Primary or primary data is data of 10 people involved in the management of Eduwisata Lontar Sewu. Secondary data were collected by researchers to support primary data. This study uses the researcher himself as a research instrument. In this study, researchers collected information about the data needed by asking, asking, listening, and taking. Researchers collect these data themselves from various sources related to their research.

The data collection technique was carried out by means of field observations, interviews with informants, and documentation of research results to obtain materials and notes in accordance with the research theory.

\subsection{Research Technic}

This qualitative research uses a variety of sources, conducted in several locations in the city of Gresik using interview techniques, observation and strengthened documentation. Data collection was carried out continuously until it was complete to obtain high data validation. The snowball sampling technique is used, where data collection will be stopped if the data obtained is saturated. The data collected is generally in quantitative form, although it does not rule out some qualitative data being obtained. Meanwhile, data processing has been carried out before entering the field, during the field process and after finishing the field. This means that data processing has been started since the researcher formulated the problem until the researcher writes the results of the study. While the focus of data processing in the qualitative research model lies in the field when data collection.

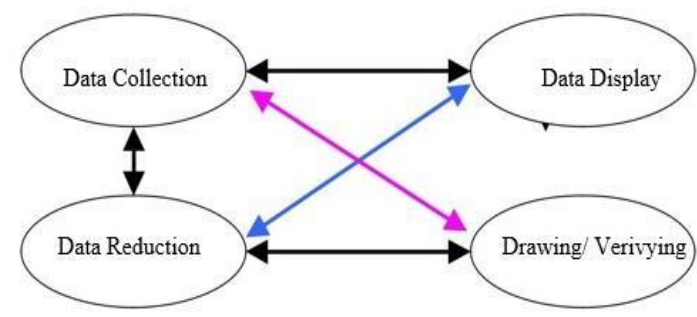

FIGURE 1. Data Processing Interactive Model Miles and Hubermann

\subsection{Data Analysis Techniques}

Analysis used interpretive descriptive supported by Miles and Huberman's theory. The purpose of data analysis is to narrow the data and limit the findings to organized, structured and meaningful data. As for the purposes of analyzing data that has been collected, analysis techniques are needed in accordance with the types of data available, including:

2.2.1 Validity, in measuring validity refers to the content and usefulness of measuring instruments, internal validity and external validity. As for what is meant by internal validity is how far a measuring instrument is able to describe the object to be measured. External validity is in relation to measuring instruments in different situations.

2.2.2 Reliability, in determining this reliability, several things can be made standard, namely:

- Accuracy or accuracy, which can contribute to a complete understanding of the object being measured.

- Stability, that is, if the measurement is replicated, it will give the same results, but with due regard to the conditions when the measurement is relatively no different.

- Homogeneity, where there is a close relationship between one another.

Meanwhile, to achieve a success in this qualitative research, it is necessary to pay attention to several things:

- Conducted in conditions as natural or natural as possible.

- Treat the person acting as an informant humanely and upholds the perspective for participation.

- The research results are discussed descriptively and synthetically.

- The deficiencies in the research will be addressed in a transparent manner. Furthermore, in this data processing, the data analysis process is good. [6]

\section{RESEARCH RESULTS AND DISCUSSION}

The Lontar Sewu educational area, which is located in Hendrosari Village, Menganti District, Gresik Regency, has various kinds of rides. Several kinds of toy rides for children are available, ranging from simple ones such as mini train, comedy heli, balloon house, rabbit garden, and flying fox for children and adults. In addition, this tourist spot which was inaugurated by the Minister of Villages, 
Disadvantaged Areas and Transmigration, Abdul Halim Iskandar, provides selfie rides among thousands of palm trees, water tourism rides, children's playgrounds, unique home gardens, culinary snacks, and family leisure area facilities.

The tour, which was opened on Sunday, 9 February 2020 in Gresik Regency, is a collaboration between Hendrosari Village and the Ministry of Health PDTT through the 2019 Local Economic Development Village Innovation Incubation Pilot Program (PIID-PEL) 2019. Village Innovation Incubation Pilot Program - Local Economic Development carried out by The Directorate of Village Economic Business Development (PUED) is a facilitation program / activity carried out to encourage the development of superior village products through a partnership between Village Community Economic Business Group (KUEMDes). This includes cooperatives, village economic institutions (BUMDes), and Professional Business Actors through a partnership concept known as the Public-Private-People-Partnership (Public-Private-People-Partnership) concept.

Before operating, Edu Wisata Lontar Sewu was packed with visitors. At least 3,000 visitors on weekends and 300 visitors on weekdays. In fact, BUMDes revenue in managing these tourist destinations has been able to provide added value to Village Budget Revenue (PADes). However, in April and May, tourist attractions were closed due to the COVID-19 pandemic. In fact, in February and March this tourist spot was able to contribute an income of IDR 56,658,000 for February and IDR 96,330,000 for March. During the pandemic period, to be precise in April 2020 and May 2020 the management of Eduwisata stopped its operations.
But they did not remain silent. Various innovations have been carried out, including by developing tourism vehicles and increasing online marketing. So it can be concluded that there are four ways to do it, namely: 1) Developing instagramable photo spots by increasing the number of photos and visitors published on Instagram, Facebook, and YouTube. 2) Developing tourism vehicles by providing new tourism vehicles in the form of an All-Terrain Vehicle in existing tourist areas. 3) Arrange traders around tourist attractions to be tidier, cleaner, and more orderly. 4) Increase the enthusiasm of YouTubers to neutralize tourist attractions.

In June 2020 these tourist attractions have not yet experienced a decline due to the initial stage of largescale relaxation of social restrictions. So that the number of tourist visits is able to record an income of Rp. 16,622,000. To overcome this condition, the Deputy Regent of Gresik Moh Qosim along with Deputy Head of the Gresik Resort Police Commissioner of Police Dhyno Indra Setiadi, Chief of Staff of the 0817 / Gresik Military District Command Major Arh Suwanto launched Tangguh Tourism at Edu Wisata Lontar Sewu, Hendrosari Village, Menganti District, Gresik Regency Wednesday (8/7/2020). This resilient tourist village has implemented health protocols to prevent the spread of Covid-19.

The result was a significant increase in income in July 2020 amounting to IDR 89,575,000 and in August 2020 reaching IDR 118,565,000. This increase in income reached ten times compared to income in May which was only IDR 16,622,000.

TABLE 1. Revenue Report Edu Wisata Lontar Sewu Tour Hendrosari Village District In 2020

\begin{tabular}{|c|c|c|c|c|c|c|c|c|}
\hline \multirow{2}{*}{ No } & \multirow{2}{*}{ Types of Tickets } & \multicolumn{2}{|c|}{ Before Pandemy } & \multicolumn{2}{|c|}{ Off } & \multicolumn{3}{|c|}{ After Pandemy } \\
\hline & & February & March & April & May & June & July & Augus \\
\hline 1 & Motorcycle Parking & 11.511 .000 & 15.072 .000 & - & - & 2.829 .000 & 12.363 .000 & 14.952 .000 \\
\hline 2 & Car Park & 1.605 .000 & 2.935 .000 & - & - & 625.000 & 2.915 .000 & 785.000 \\
\hline 3 & Rides & 17.775 .000 & 26.625 .000 & - & - & 2.040 .000 & 21.135 .000 & 22.425 .000 \\
\hline 4 & ACCU Car & 1.170 .000 & - & - & - & - & - & - \\
\hline 5 & Scooter & 325.000 & - & - & - & - & - & - \\
\hline 6 & Water Bike & 10.460 .000 & 14.940 .000 & - & - & 3.460 .000 & 11.200 .000 & - \\
\hline 7 & Adult Flaying Fox & - & - & - & - & - & - & - \\
\hline 8 & $\begin{array}{l}\text { Flaying Fox } \\
\text { Children }\end{array}$ & - & - & - & - & - & - & - \\
\hline 9 & Spider Nett & - & - & - & - & - & - & - \\
\hline 10 & Tourism Entrance & 13.812 .000 & 36.758 .000 & - & - & 7.668 .000 & 41.962 .000 & 80.403 .000 \\
\hline 11 & Lontar Cafe & & & & & & & \\
\hline
\end{tabular}




\begin{tabular}{|l|l|l|l|l|l|l|r|}
\hline Amount & 56.658 .000 & 96.330 .000 & - & - & 16.622 .000 & 89.575 .000 & 118.565 .000 \\
\hline Total Income & & 152.988 .000 & & & & & \\
\end{tabular}

\section{CONCLUSION}

To increase tourist visits, what needs to be done is:

- Adding tourist rides so that visitors are not bored. This has been done by adding rides for children's games.

- Promote tourist attractions through online media. This has been done by neutralizing tourist attractions through YouTubers who have many followers.

- Arranging UKM selling around tourist attractions.

- Arrange selfie spots to make them more attractive to tourists.

\section{ACKNOWLEDGMENTS}

The authors would like to thank the Universitas Muhammadiyah Gresik for their financial support and the completion of this research.

\section{REFERENCES}

[1] Cooper, C., \& Hall, C. M. (2008). Contemporary tourism: An international approach. Routledge.

[2] Gao, J., \& Wu, B. (2017). Revitalizing traditional villages through rural tourism: A case study of Yuanjia Village, Shaanxi Province, China. Tourism Management. https://doi.org/10.1016/j.tourman.2017.04.00 3

[3] Hardani, H. A., Ustiawaty, J., Istiqomah, R. R., Fardani, R. A., Sykmana, D. J., \& Auliya, N. H. (2020). Buku Metode Penelitian Kualitatif \& Kuantitatif. Yogyakarta: $C V$. Pustaka Ilmu Group.

[4] Jatmiko, R. D., \& Andharini, S. N. (2012). Analisis experiential marketing dan loyalitas pelanggan jasa wisata (Studi pada Taman Rekreasi Sengkaling Malang). Jurnal Manajemen Dan Kewirausahaan, 14(2), 128137.

[5] Kurniawan, A., Komara, B. D., Ramdhani, M. G., \& Ragillia, R. (2020). Strengthening Management of BUMDes to Increase Income and Welfare of Hendrosari Village, Menganti District, Gresik Regency. Kontribusia (Research Dissemination for Community Development).

https://doi.org/10.30587/kontribusia.v3i2.132 8

[6] Sukmayati, D. (2014). Strategi Komunikasi Pemasaran Harian Joglosemar Dalam Upaya Menarik Minat Pemasang Iklan (Studi Deskriptif Kualitatif Strategi Komunikasi
Pemasaran Harian Joglosemar Dalam Upaya Menarik Minat Pemasang Iklan Periode Februari-April 2013). Universitas Muhammadiyah Surakarta.

[7] Hau, T. C., \& Omar, K. (2014). The impact of service quality on tourist satisfaction: the case study of Rantau Abang Beach as a turtle sanctuary destination. Mediterranean Journal of Social Sciences, 5(23), 1827. 